\title{
JUDICIAL CONTROL OF ADMINISTRATIVE ACTS AND MEASURES REGARDING UNLAWFUL RESIDENCE OF FOREIGNERS IN CROATIA IN THE EUROPEAN CONTEXT
}

\author{
Ana Đanić Čeko, PhD, Assistant Professor \\ Josip Juraj Strossmayer University of Osijek, Faculty of Law \\ Stjepana Radića 13, Osijek, Croatia \\ adjanic@pravos.hr
}

\author{
Mateja Held, PhD, Assistant Professor \\ University of Zagreb, Faculty of Law \\ Trg Republike Hrvatske 14, Zagreb, Croatia \\ mateja.held@pravo.hr
}

\begin{abstract}
Accession of the Republic of Croatia to the EU has prompted numerous legal reforms and amendments. One of them was a major administrative court reform the main result of which was the new Administrative Disputes Act adopted in 2010 and coming into force 2012. One of the issues it regulates is the judicial control in general, and together with Foreigners Act from 2011 defines control of administrative acts and measures regarding unlawful residence of foreigners in Croatia, which is the subject of the analysis in this paper. The paper is divided in three main parts. Basic features of migrations and its consequences on European and domestic regulation are explained in the first part of the paper. Second part of the paper is focused on the procedural aspect of migrations, namely on the unlawful residence of foreigners from the perspective of the administrative courts. The final part of the paper draws certain conclusions based on the preceding analysis. The main focus of the paper is an analysis of the specificities of administrative courts' control, such as the shortness of deadlines, oral hearings as an exception, particularities of the engagement of the parties before the court, etc. Paper elaborates in detail the normative arrangement of unlawful residence in Croatia and differences between Foreigners Act and Administrative Disputes Act through analysis of the relevant domestic and European regulative framework and case law. With this, the paper hopes to contribute in solving at least some of the numerous legal problems associated with the current migrant and refugee crisis from the perspective of the European and Croatian administrative law.
\end{abstract}

Keywords: immigration, unlawful residence, detention, judicial review, Council of Europe, European Union, Croatia 


\section{INTRODUCTION}

Accession of the Republic of Croatia to the European Union (hereinafter: EU) has prompted numerous legislative reforms and amendments. One of them is a major administrative courts' reform ${ }^{1}$ that resulted in the adoption of the new Administrative Disputes Act (hereinafter: ADA) which was accepted in the parliament in 2010, and was applied since 2012. ${ }^{2}$ After joining the EU, ${ }^{3}$ the Republic of Croatia has become a kind of south-eastern frontier for the rest of EU, ${ }^{4}$ which has become particularly important with the rise of migration over the last few years, due to which growth it is often referred to as a so-called migrant or refugee crisis. ${ }^{5}$ Due to a specific role of the Republic of Croatia in these processes, ${ }^{6}$ which is undoubtedly for the most part a result of its territorial position, the Croatian legislator has

1 More on administrative courts' reform in Croatia see in: Medvedović, D., Novi sustav upravnog sudovanja, in: Đerđa, D.; Šikić, M., Komentar Zakona o upravnim sporovima, Novi informator, Zagreb, 2012, pp. 17-75; Đerđa, D. Šikić; M, Komentar Zakona o upravnim sporovima, Novi informator, Zagreb, 2012; Šikić, M., Pravo na sudenje u razumnom roku u upravnosudskim postupcima - novi problemi i izazovi, in: Uzelac, A.; Garašić, J.; Maganić, A. (eds.), Zbornik radova u čast 70. rođendana prof. dr. sc. Mihajla Dike - Djelotvorna pravna zaštita u pravičnom postupku, Izazovi pravosudnih transformacija na jugu Europe - Liberamicorum Mihajlo Dika. Sveučilište u Zagrebu, Pravni fakultet, 2013, p. 990; Rajko, Alen, Novi Zakon o upravnim sporovima: odluke Upravnog suda RH u prvostupanjskome upravnom sporu, Hrvatska pravna revija, vol. 10, No. 10, 2010, p. 84

2 Administrative Disputes Act, Official Gazette (hereinafter: OG), No. 20/10, 143/12, 152/14, 94/16, 29/17. (hereinafter: ADA)

3 Croatia had specific position on migrant routes even before joining the EU, and according to Ivanda, the rise of migration through Croatia, will influence on the rise of illegal migration as well (Ivanda, S., Suvremene ilegalne migracije u Republici Hrvatskoj, Policija i sigurnost, vol. 11, No. 1-3, 2002, p. 85. On the same topic see also: Ivanda, S.; Šuperina, M., Migracije, granična policija, ilegalni prelasci $i$ krijumičarenje ljudi preko državne granice, Pravni vjesnik, vol. 16, No. 3-4, 2000, p. 280

4 According to Gregurović and Mlinarić, Croatia was interested to migrants mostly as a transit country (Gregurović, S.; Mlinarić, D., The Challenges of Migration Policies in Croatia: Migration History, Trends and Prospects, AEMI Journal, vol 10, special issue on Migration History Matters, 2012, p. 106

5 Bulli, G.; Soare, S. C. Immigration and the Refugee Crisis in a New Immigration Country: The Case of Italy, Croatian and Comparative Public Administration, vol. 18, No. 1, 2018, p. 127; Speer, B., External and Internal Effects of How Austria Has Handled the Refugee Crisis, Croatian and Comparative Public Administration, vol. 18, No. 2, 2018, p. 248; European Commission, Progress Report on the Implementation of the European Agenda on Migration, COM (2018, No. 2, pp. 247-268); European Commission, Progress Report on the Implementation of the European Agenda on Migration, COM(2018) 301 final, 18 May 2018,301 final, 18 May 2018, p. 5, [https://ec.europa.eu/home-affairs/sites/homeaffairs/ files/what-we-do/policies/european-agenda-migration/20180516_progress-report-european-agenda-migration_en.pdf] Accessed 04.03.2019. The Report provides data on the main migration routes in Europe (Eastern Mediterranean, Western Balkans, Central Mediterranean and Western Mediterranean/Atlantic route) and EU Support to Migration Management. Together with Albania, FYROM, Serbia and Bosnia and Herzegovina, Croatia is in the Report mentioned as a country on the Western Balkans route

6 All borderline EU countries are facing similar challenges on migration issues. For Romanian example see in: Doncea, A., Illegal migration - a current European issue, European Journal of Public Order and National Security, vol. 2, No. 4, 2015, pp. 21 -26. Docnea has mentioned so-called „Black Sea route“, 
given priority to the internal security of the state by amending the basic regulation in this area-Foreigners Act (hereinafter: FA) ${ }^{7}$ and strengthening of police powers ${ }^{8}$ with the aim of deporting foreigners with unlawful residence as soon as possible.?

On the one hand, the procedures related to unlawful ${ }^{10}$ residence should definitely be effective but, on the other hand, the principle of proportionality and the preservation of fundamental human rights and freedoms have to be observed. Thereby in this paper consideration is given to the degree of achievement of certain principles envisaged by the General Administrative Procedure Act (hereinafter: GAPA), ${ }^{11}$ such as the principle of effectiveness, proportionality and protection of the rights of the parties. Further, the paper elaborates in detail the normative arrangement of unlawful residence in Croatia and differences between FA and ADA through an analysis of relevant domestic and European regulative framework and case law. Since the fundamental right to the movement of persons is very limited in these proceedings, attention will be given to this right guaranteed in numerous provisions of the Council of Europe and in documents of the EU.

alongside main migrant routs in the Commission Report. See Docnea, op. cit., p. 23. For Italy see in: Bull; Soare, op. cit. note 5, pp. $130-137$

7 Foreigners Act, OG, No. 130/11, 74/13, 69/17, 46/18 (hereinafter: FA)

8 Hellenthal has mentioned several measures existing during 90 -ies for combating illegal entrance on national and EU level and their reflection to federal protection of borders in Germany (Hellenthal, M., Granične kontrole kao dio nacionalnog i europskog sustava za kontrolu kriminala $i$ migracije = ${ }^{G}$ renz kontrollen als Teilnationalen und europaeischen Systems zur Kriminalitaets-und Wanderugkontrolle, translation from German: Dragica Dragičević, Izbor članaka iz stranih časopisa, vol. 35, No. 1, 1995, pp. 31-34

9 Heads of police of the country's most effected by migration have agreed on common standards for improving cooperation in migration flow management in meeting held in Zagreb, for example unified registration form, etc. See in: Joint Statement of heads of police Services, [https://www.mup.hr/UserDocsImages/topvijesti/2016/veljaca/migranti_sastanak/joint_statement.pdf] Accessed 04.03.2019

10 ECtHR primarily uses term „unlawful residence“, but CJEU uses terms such as illegal migration, illegal crossing, etc. For the purposes of the paper, authors use both terms, respecting the context

11 General Administrative Procedure Act, OG, No. 47/09 


\section{EUROPEAN STANDARDS IN PROCEDURES OF UNLAWFUL RESIDENCE}

\subsection{Council of Europe standards}

Human right treaties such as the Universal Declaration on Human Rights ${ }^{12}$ and European Convention on Human Rights ${ }^{13}$ provide basic legal framework for the protection of all human beings, including migrants regardless of their nationality. ${ }^{14}$ For the purposes of this paper which is focused on the Croatian law in the European context, we will analyse certain provisions of the ECHR which set minimum standards for High Contracting Parties, namely right to liberty and security regulated by Art. 5 and freedom of movement provided in Art. 2 and 4 of Protocol 4 of the ECHR. ${ }^{15}$ Both rights can be restricted under specific circumstances, but minimum standards in dealing with those cases should be respected, such as speedy and effective procedures, all explained and analysed in the ECtHR case law.

National procedures include both administrative measures, since irregular migration is constituted as administrative offence and not criminal offence, ${ }^{16}$ and court proceedings reviewing legality of administrative actions concerning migrants. Administrative measures are regulated in domestic provisions of various foreigners or

12 Universal Declaration on Human Rights was proclaimed by the United Nations General Assembly in Paris on 10 December 1948 as a common standard of achievements for all peoples and all nations (http://www.un.org/en/universal-declaration-human-rights/). Text of the Declaration available at [http://www.un-documents.net/a3r217a.htm] Accessed 19.02.2019

13 European Convention on Human Rights is an international treaty created by the Council of Europe in 1950. ECHR came into force in 1953 and since then it was amended by its protocols widening rights guaranteed in original text

14 Lambert, H., The position of aliens in relation to the European Convention on Human Rights, Council of Europe Publishing, Strasbourg, 2007, p. 9;

Report of the Special Rapporteur on the human rights of migrants, A/HRC/38/41, 4 May 2018, [https:// reliefweb.int/sites/reliefweb.int/files/resources/G1812517.pdf] Accessed 08.02.2019, pp. 5-6

Exceptions on admissibility criteria regarding foreigners include the right to enter and stay in the country and to vote and to be elected (Crepéau, F., Statement by the UN Special Rapporteur on the Human Rights of migrants, PGA Plenary Session - Criminalization of Migrants, New York, 2013, p. 1, [https://www.ohchr.org/_layouts/15/WopiFrame.aspx?sourcedoc=/Documents/Issues/SRMigrants/ Speech/StatementPGAPlenaryCriminalization.doc\&action=default\&DefaultItemOpen=1] Accessed 08.02.2019)

For the admissibility criteria in general before ECtHR see in Practical Guide on Admissibility Criteria, Council of Europe, last updated 31 December 2018. Accessed 19 February 2019

15 "Art. $5 \$ 1$ of the Convention concerns the deprivation of liberty, Art. 2 of Protocol No. 4 governs mere restrictions on the liberty of movement. However, the difference between both concepts is not one of nature or substance but one of degree or intensity"(Berdzenshvili and Others v. Russia (2017) $\$ 108$ )

16 Crepéau, op. cit. note14 
immigration acts ${ }^{17}$ and by-laws. ${ }^{18}$ Court proceedings, on the other hand, can be regulated in Administrative Disputes Act on general level with details provided in other acts regarding foreigners. ${ }^{19}$

ECHR guarantees everyone who is deprived of his liberty by arrest or detention to undertake proceedings by which the lawfulness of his detention shall be decided speedily by a court and his release ordered if the detention is unlawful. ${ }^{20} \mathrm{ECtHR}$ finds violation of standards guaranteed in ECHR mostly by declaring domestic procedures as being not sufficiently effective nor speedy as is needed in sensitive cases like immigration. ${ }^{21}$ For example in Alimov v. Turkey the ECtHR found violation of Article $5 \$ 4$ because Turkish legal system at the relevant time did not provide persons in the applicant's position with a remedy whereby they could obtain judicial review of the lawfulness of their detention. ${ }^{22}$ In $M$. and Others $v$. Bulgaria, two different governmental bodies had issued two separate orders for the detention of the applicant, ${ }^{23}$ and he lodged an appeal before administrative courts in each case. ${ }^{24}$ In the procedure concerning the first order, court did not reach decision in speedy procedure since proceedings lasted for more than two years. ${ }^{25} \mathrm{In}$ the second order procedure, Sofia City Court refused the first applicant's request for a stay of enforcement of the detention order. ${ }^{26} \mathrm{ECtHR}$ found serious violations of the right to take proceedings speedily by a court. ${ }^{27}$

17 For example, the entry and residence of immigrants are governed by following laws in Russia: Federal Law no. 115-FZ of 25 July 2002 on the Legal Status of Foreign Nationals in the Russian Federation and Federal Law no. 109-FZ of 18 July 2006 on the Registration in the Russian Federation of Migrants who are Foreign Nationals or Stateless Persons (Case of Berdzenishvili and others v. Russia (2017), $\mathbb{S}$ 32), and The Aliens and Immigration Law and the Refugee Law (Case of M. A. v. Cyprus (2013), $\$ \$ 61$ et $s q q$.)

18 Ordinance on Treatment of Citizens of the Third Countries, OG, No. 68/2018

19 See Croatian regulation, ADA and FA

20 Art. $5 \$ 4$ of the ECHR

21 Sitaropoulos, N., Judicial Review of Migrant Detention in Europe: In Search of Effectiveness and Speediness (OxHRH Blog, 27 January 2014) [http://humanrights.dev3.oneltd.eu/?p=4126], [http://ohrh.law. ox.ac.uk/judicial-review-of-migrant-detention-in-europe-in-search-of-effectiveness-and-speediness] Accessed 08.02.2019

22 Alimov v. Turkey (2016), \$50. See also Abdolkhan and Karimnia v. Turkey (2009), \$\$139. - 142, Z. N. S. v. Turkey (2010), $\$ \$ 58-63$, Tehrani and Others v. Turkey (2010), $\$ \$ 74-80$, Batyrkhairov v. Turkey (2018), \$\$66 - 69, Amerkhanov v. Turkey (2018), \$\$ 71 - 74

23 The first order was issued on 6 December 2005, and the second order on 12 October 2006 (See M. and Others v. Bulgaria (2011) \$\$11-17)

24 Applicant lodged an appeal against the first order on 20 October $2006(\$ 23)$, and against the second order on 26 October $2006(\$ 35)$

25 Judgement was reached on 2 April 2009 (M. and Others v. Bulgaria, \$38)

$26 \quad$ Ibid.,\$\$35-38

$27 \quad$ Ibid., $\$ \$ 82-83$ 
On the other hand, by the provisions of the ECHR, the High Contracting Parties are allowed to "control the liberty of aliens in an immigration context", ${ }^{28}$ and they can "remove aliens as part of their national sovereignty". ${ }^{29}$ If these processes are not conducted lawfully, human rights can be infringed by the police officers while exercising their duty in connection of irregular migration. Methods of conducting the legitimation of foreigner, and their detention should be strictly defined by the law. Under the ECHR, detention, ${ }^{30}$ as a first measure in the unlawful residence treatment, must be "carried out in good faith; it must be closely connected to the purpose of preventing unauthorized entry of the person to the country; the place and conditions of detention should be appropriate, bearing in mind that the measure is applicable not to those who have committed criminal offences but to aliens who, often fearing for their lives, have fled from their own country; and the length of the detention should not exceed that reasonably required for the purpose pursued “. ${ }^{31}$ Detention is not punishment and must not be punitive in character. ${ }^{32}$

The ECtHR gives a wide margin of discretion to the states in relation of art 5 (1) f. ${ }^{33}$ Nonetheless, judicial review of the legality of the detention must be guaranteed "as a safeguard against the arbitrariness of the measure, including the domestic law upon which it is based". ${ }^{34}$ In the analysed cases judicial control was not as effective and as speedy as needed. Guidelines provided by the ECtHR in Suso Musa v. Malta pilot-judgement ${ }^{35}$ where ECtHR in $\$ \$ 119-123$ highlighted the necessity of general measures at the national level which will establish judicial mechanism providing for speedy and fair judicial review of migrant detention. In M.A. $v$ Cyprus the ECtHR explained essential conditions for lawful detention in $\$ \$ 102-$

$28 \quad$ Khlaifia and Others v. Italy (2016), $\$ 89$ and Guide on Article 5 of the European Convention on Human Rights, p. 26, last updated 31. 12. 2018, [https:/www.echr.coe.int/Documents/Guide_Art_5_ENG. pdf] Accessed 19.02.2019

29 Lambert, op. cit. note 14, p. 17

30 For principles of the detention of aliens see Lambert, ibid., p. 27

31 Saadi v. UK (2008), $\$ 74$, and Guide on Article 5 of the European Convention on Human Rights, p. 27, last updated 31 December 2018, [https://www.echr.coe.int/Documents/Guide_Art_5_ENG.pdf] Accessed 19.02.2019

32 Principles on the immigration detention are also summarized in the European Committee for the Prevention of Torture and Inhuman or Degrading Treatment or Punishment (CPT) factsheet form March 2017, CPT/Inf (2017)3, p. 1, [https://rm.coe.int/16806fbf12] Accessed 01.03.2019

33 See for example Chahal v. UK (1996), $\$ 123$

34 Lambert, op.cit. note 14, p. 32

35 More on Pilot-Judgement Procedure before ECtHR see in: The Pilot-Judgment Procedure Information Note issued by the Registrar, [https://www.echr.coe.int/Documents/Pilot_judgment_procedure_ENG. pdf] Accessed 08.02.2019 
105 by referring to Amnesty International reports. ${ }^{36}$ Both previously mentioned judgements are of great importance for national judicial proceedings. Right to the effective remedies ${ }^{37}$ is in close connection to an effective and speedy judicial review. ${ }^{38}$ Strict standards on duration of detention and its determination are set in\$ 162 of M. A. v. Cyprus and in some other cases such as Sarbanv. Moldova, ${ }^{39}$ Kadem v. Malta, ${ }^{40}$ Rehbock v. Slovenia ${ }^{41}$ etc. According to an opinion expressed in literature, if there exists a bi-level of judicial review, ${ }^{42}$ both levels should meet above mentioned standards. ${ }^{43}$

Article 2 of the Protocol 4 guarantees freedom of movement to everyone who is lawfully on the territory of the State. Although in the Article 4 of the same Protocol condition of lawful or unlawful residence is not mentioned directly, ECtHR stipulates clearly that a collective expulsion ${ }^{44}$ of aliens is prohibited in cases of their unlawful residence, "whether they are merely passing through a country or reside or are domiciled in it, whether they are refugees or entered the country on

36 Punishement without a crime - Detention of Migrants and Asylium Seekers in Cyprus, Amnesty International, 2012, [https://www.amnesty.org/download/Documents/20000/eur170012012en.pdf] Accessed 05.03.2019 and Annual Report for 2011 (see M. A. v. Cyprus (2013)\$105)

37 According to Kitsakis, supervision of the legality of detention after the person has been released from detention, falls within the scope of the right to the effective remedy in Article 13 of the ECHR (Kitsakis, Y., Protecting Migrants under the European Convention on Human Rights and the European Social Charter, Council of Europe, 2013, p. 45)

38 See M. A. v. Cyprus (2013), $\$ 160$

39 Sarban v. Moldova (2006), $\$ \$ 118-124$

40 "The competent court should examine not only compliance with the procedural requirements set out in domestic law, but also the legitimacy of the purpose pursued by the arrest and the ensuing detention and should have the power to order the termination of the deprivation of liberty if it proves unlawful (Kadem v. Malta (2003), \$41)

$41 \quad$ Rehbock v. Slovenia (2000), \$\$82 - 88

42 On the first level, Croatia has four administrative courts, and on second level High Administrative Court of the Republic of Croatia (Art. 14 (3) of the Courts Act, OG, No. 28/13, 33/15, 82/15, 82/1 6, 67/18 and Art. 12 (1) of the ADA, OG, No. 20/10, 143/12, 152/14, 94/16, 29/17 )

43 Djalti v. Bulgaria (2013), \$64; Sitaropoulos, op. cit.note 21; Guide on Article 5 of the European Convention on Human Rights, p. 40

44 For explanation of the term "collective expulsion" see Berdzenishvili and Others v. Russia (2017) \$79, Khlaifia and Others v. Italy (2016) \$\$237-238, Georgia v. Russia (I) (2014), $\$ 160$ 
their own initiative, or whether they are stateless or possess another nationality”45. $\mathrm{ECtHR}^{46}$ found violation of the Article 4 of the Protocol in six cases. ${ }^{47}$

The case law related to the mentioned provisions of the ECHR is of importance because Croatia could easily find itself as the respondent state in the procedures before the ECtHR. Great number of migrants were passing through Croatian territory recently, where upon Croatian state bodies were exercising their power to detain citizens, and in those proceedings fundamental rights and freedoms could easily be violated. If aliens were on the territory unlawfully, they were detained, brought before state bodies and courts. Last two decisions in $2018^{48}$ regarding aliens were reached in October and December of 2018 by the Constitutional Court of the Republic of Croatia. Although mentioned procedures are in Croa-

45 Guide on Article 4 of Protocol No. 4 to the European Convention on Human Rights, Council of Europe, p. 6, last updated 31 December 2018. [https://www.echr.coe.int/Documents/Guide_Art_4_Protocol_4_ENG.pdf] Accessed 20.02.2019

46 In its argumentation, the ECtHR case law both international and European documents and reports on foreigner status in the third countries, for example in Khlaifia and Others v. Italy (2016): Directive 2008/115/EC(\$\$41 - 45), Draft articles on the expulsion of aliens (2014) adopted by The International Law Commission (ILC) (\$\$46 - 47), Ad Hoc Sub-Committee on the large-scale arrival of irregular migrants, asylum-seekers and refugees on Europe's southern shores (2011) by the Council of Europe's Parliamentary Assembly (PACE) (\$49), Amnesty International findings and recommendations to the Italian authorities following the research visit to Lampedusa and Mineo(2011) by Amnesty International (\$50); in M. A. v. Cyprus (2013): Guidelines of the Committee of Ministers of the Council of Europe (2009) (\$94), Recommendation (CommDH(2001)19) of the Commissioner for Human Rights (\$95), European Commission against Racism and Intolerance (ECRI) reports on Cyprus (2005 and 2011) (\$96 97), Directive 2005/85/EC (\$99), Report concerning the detention of migrants and asylum-seekers in Cyprus (2012) by Amnesty International ( $\$ \$ 100-104)$, Annual Amnesty International Report (2011) $(\$ 105)$. ECRI Reports on Croatia are available at: [https://www.coe.int/en/web/european-commission-against-racism-and-intolerance/croatia] Accessed 20.02.2019; in Hirsi Jamaa and Others v. Italy (2012): Geneva Convention relating to the Status of Refugees (1951) (\$\$22 - 23), United Nations Convention on the Law of the Sea ("the Montego Bay Convention") (1982) (\$24), International Convention on Maritime Search and Rescue ("the SAR Convention") (1979 amended in 2004) (\$25), Protocol against the Smuggling of Migrants by Land, Sea and Air, supplementing the United Nations Convention against Transnational Organised Crime ("the Palermo Protocol") (2000) (\$26), Resolution 1821 of the Parliamentary Assembly of the Council of Europe (2011), Charter of Fundamental Rights of the European Union (2000) (\$28), Schengen Agreement (1985) (\$29), Council Regulation (EC) no. 2007/2004 of 26 October 2004 establishing a European Agency for the Management of Operational Cooperation at the External Borders of the Member States of the European Union (Frontex) (\$30), Regulation (EC) No. 562/2006 of the European Parliament and of the Council of 15 March 2006 establishing a Community Code on the rules governing the movement of persons across borders (Schengen Borders Code)(\$31), etc.

47 Čonka v. Belgium (2002), Georgia v. Russia (I) (2014), Shioshvili and Others v. Russia (2017), Berdzenishvili and Others v. Russia (2017), Hirsi Jamaa and Others v. Italy (2012) Sharifi and Others v. Italy and Greece (2015) (Guide on Article 4 of Protocol No. 4 to the European Convention on Human Rights, Council of Europe, p. 7)

48 Decision U-III-3124/2018 from 17 October 2018 and U-IIIBi/1385/2018 from 18 December 2018 of the Constitutional Court of the Republic of Croatia 
tian legislature defined as urgent, ${ }^{49}$ all administrative and judicial remedies have to be exhausted prior the procedure before ECtHR. It is not to be expected that the ECtHR has had an opportunity between then and now to reach a decision, even if plaintiff had submitted application to the ECtHR, which is not known for a fact. ${ }^{50}$

\subsection{European Union standards}

Over the past few years, EU was confronted with large influx of migrants mostly due to the war and economic reasons. As a sort of a border towards the rest of the Europe, Croatia has had a specific situation with a large number of migrants crossing through the country every day in legal or illegal manner. EU case law and regulations give us certain definitions of the terms which are important for national legal systems such as illegal stay, ${ }^{51}$ illegal crossing, illegal transit, unlawful residence, first point entry, ${ }^{52}$ etc. ${ }^{53}$ Migrants, as vulnerable group of people, ${ }^{54} \mathrm{can}$ easily be discriminated and their rights at this point can easily be infringed. ${ }^{55}$

49 Administrative Court should decide in five days on detention of foreigner (Art.135 (4) of the FA, OG, No. 130/11, 74/13, 69/17, 46/18)

50 The exhaustion of the domestic remedies in Croatian law implies conducting of the administrative procedure, administrative dispute (both levels) and the procedure before Constitutional Court based on the constitutional complaint

51 In case C-646/16, in $\$ 12$ Court highlights that according to the Return Directive "illegal stay" means the presence on the territory of a Member State of a third-country national who does not fulfil, or no longer fulfils the conditions of entry as set out in Article 5 of the Schengen Borders Code or other conditions for entry, stay or residence in that Member State“ and in $\$ 63$ that „concept of 'illegal stay', which is not to be confused with that of 'illegal entry" and 'irregular crossing' of the border of a Member State cannot be construed in the same way as that of an 'illegal stay'". See also judgements on preliminary ruling in following cases regarding illegal entry: C-240/17, C-225/16, C-181/16, C-82/16C-18/16, C-601/15C-218/15, C-133/15, C-47/15, C-544/13, C-249/13, C/166/13, C-225/12, etc.

52 Frantziou, E., Staiger, U, Chaytor, S., Refugee Protection, Migration and Human Rights in Europe, UCL policy briefing - May 2014, p. 2, [https:/www.ucl.ac.uk/public-policy/sites/public-policy/files/migrated-files/Refugee_protection_FINAL.pdf] Accessed 07.03.2019

53 Project „Clandestino“ funded by the EU (2007-2009), (for more see inhttps://ec.europa.eu/knowledge4policy/dataset/ds00039_en, accessed on 7 March 2019), adopted terms "undocumented" and "irregular migration" and "undocumented immigrant". See in: Morehouse, C.; Blomfiled, M., Irregular Migration in Europe, migration Policy Institute, 2011

54 Office of the High Commissioner of Human Rights provide us with reasons for vulnerability of migrants, such as their inherent characteristics, for example children, women at risk, people with disabilities, older persons, conditions people are leaving behind in their countries of origin, the circumstances in which they are compelled to move, or because of the virtue of the conditions in which they are received. [https://www.ohchr.org/en/Issues/Migration/Pages/MigrantsinLargeMovements.aspx] Accessed 07.03.2019

55 For more detail review of vulnerabilities in immigration cases see in: IOM Submission to the Working Group on Arbitrary Detention, International Standards on Immigration Detention and non-custodial 
The legal basis for migration includes both primary ${ }^{56}$ and secondary legislation ${ }^{57}$ of the EU. The Charter of Fundamental Rights of the European Union, as a key document providing the catalogue of rights, in Article 45(2) guarantees freedom of movement and residence in accordance with the Treaty establishing the European Community, to nationals of third countries legally resident in the territory of a Member State. With respect of the aim of the paper, we will focus on illegal migration, namely detention of the third-country nationals and extension of the detention, and judicial control of the decisions of the detention.

In the relevant EU case law, the most cited is Directive 2008/115/EC 58 of the European Parliament and of the Council of 16 December 2008 on common standards and procedures in Member States for returning illegally staying third-country nationals (hereinafter Return Directive).$^{59}$ Return Directive set out rules on detention of the third - country nationals in Articles $15-18$. The Member States are obliged to put in place effective remedies against those decisions, meaning that they are obliged to provide a speedy judicial review of the lawfulness of the detention. It also provides that the third-country nationals have to be released immediately if the detention is not lawful. ${ }^{60}$ Those provisions integrate human rights principles, ${ }^{61}$ espe-

measures, 2011, pp. 5-6

56 See Art. 3(2) of the Treaty on European Union (TEU); Art. 21 of the Treaty on the Functioning of the European Union (TFEU); Titles IV and V of TFEU

57 Geddes and Achtnich analyze certain directives on immigration issues, namely The Racial Equality Directive (2000/43/EC), Family Reunification (Council Directive 2003/86/EC of 22 September 2003), Employment Equality Directive (2000/78/EC) and Long-Term Residence Directive (Council Directive 2003/109/EC of 25 November 2003). Geddes A.; Achtnich M., Research-Policy Dialogues in the European Union. In: Scholten P., Entzinger H., Penninx R., Verbeek S. (eds) Integrating Immigrants in Europe. IMISCOE Research Series. Springer, Cham, 2015, [https://link.springer.com/ chapter/10.1007/978-3-319-16256-0_16] Accessed 07.03.2019

58 European Parliament and Council Directive 2008/115/EC on common standards and procedures in Member States for returning illegally staying third-country nationals [2008] OJ L 348/98

59 Republic of Croatia has implemented Return Directive (see general provisions of FA)

60 Judgment in Case C-383/13 PPU, Press Release, $\$ 1$

${ }_{61}$ Returns Directive mentions three principles which need to be respected or of which due account needs to be taken, namely non-refoulement (articles 4(b), 5 and 9(1)(a)), family unity (articles 5(b) and 14(1) (a)) and the best interests of the child (articles 5, 10(1) and 17(5)). See also in: Baldaccini, A. TheEu Directive on Return: Principles And Protests, Refugee Survey Quarterly, Vol. 28, No. 4 UNHCR [2010], p. 126. On non-refoulment principle see in: Lalić Novak, G., The Principle of Non-Refoulement and Access to Asylum System: Two Sides of the Same Coin, Migracijske Iietničke teme, vol. 31, No. 3, 2015, pp. 365-385; Rodin, S., Načelo non-refoulement u hrvatskom pravu. Informator: instruktivno-informativni list za ekonomska i pravna pitanja, No. 6048, 2012, pp. 1-3 
cially principle of proportionality. ${ }^{62}{ }^{63}$ According to this Directive, detention should be ordered by administrative or judicial authorities. ${ }^{64}$

Conditions on detention are set in Article 16 of the Return Directive. ${ }^{65}$ Leading rulings on judicial control of the grounds of detention and extension of the detention are $G$ and $R^{66}$ and Mahdi. ${ }^{67}$

In $G$ and $R$ the issue was an infringement of the applicants' right to be heard before the administrative bodies in Netherlands who ordered the detention under a removal procedure. They lodged judicial actions before first instance court challenging the decisions to extend their respective detention. Appeals were lodged to Council of State and that court made a request for preliminary ruling to the Court of Justice. The Court of Justice concluded that "the national court must assess whether such an infringement has actually deprived the party relying thereon of the possibility of better arguing its defence to the extent that the outcome of the administrative procedure that led to the decision maintaining the detention could have been different".

Mr. Mahdi was a Sudanese national without a valid identity document and was arrested in Bulgaria. Bulgarian authorities ordered his detention and they brought the case before Administrative Court seeking the extension of the detention on the grounds of the risk of Mr. Mahdi absconding and a lack of cooperation. Bulgarian Court has referred a number of questions before the Court of Justice. Summarisation of the Court of Justice ruling is: "any extension of detention must be in writing, with reasons being given in fact and in law, and be subject to a review of legality by a court". ${ }^{68}$ In conclusion of this chapter we may say that the weight of the decision making and observing that human rights are respected is on national administrative bodies and on the national courts.

62 Thielemann states that The Returns Directive „made immigration detention subject to the principle of proportionality" (Thielemann, E-R., How Effective are National and Eu Policies in the Area of Forced Migration?, Refugee Survey Quarterly, vol 31, No. 4, 2012, p. 31)

63 Costello, C., Human Rights of Migrants and Refugees in European Law, Oxford University Press, 2016, p. 298

${ }^{64}$ Art. 15(2) of the Return Directive

65 On the detention under the Return Directive see in: Baldaccini, A., The Return and Removal of Irregular Migrants under EU Law: An Analysis of the Returns Directive, European Journal for Migration and Law, vol. 11, 2009, pp. 15-16 and Basilien-Gainche, M-L., Immigration Detention under the Return Directive: The CJEU Shadowed Lights, European Journal of Migration and Law, vol. 17, 2015, pp. 104-126

${ }_{66}$ Judgment in Case C-383/13 PPU G and R v Staatssecretaris van VeiligheidenJustitie, PRESS RELEASE No 100/13

67 Judgment in Case C-146/14 PPU Bashir Mohamed Ali Mahdi, PRESS RELEASE No 80/14

68 Ibid. 


\section{SPECIAL ADMINISTRATIVE PROCEDURES REGARDING UNLAWFUL RESIDENCE IN CROATIA}

First of all, it is to be emphasized that in accordance with the Art. 32 (1) of the Constitution of the RC every individual, lawfully present on the Croatian territory, has the right of freedom of movement and a free choice of one's own place of residence. ${ }^{69}$ The right of movement, entering and departing the country can be exceptionally limited by law in cases where this action is necessary due to protection of legal order, health, rights and freedoms of others. ${ }^{70}$

The implementation of special administrative procedure regarding the decisionreaching process about the placement in reception centres (hereinafter: $\mathrm{RC})^{71}$ of the Ministry of the Interior (hereinafter: MI ${ }^{72}$ through competent police $\mathrm{PD} /$ $\mathrm{PS}^{73}$ due to unlawful residence in the $\mathrm{RC}$ is normed by the provisions Art. 135 of the FA. The legal framework connected to unlawful residence is stipulated in Ordinance on Treatment of Citizens of the Third Countries and Ordinance on Stay in the Reception Centre for Foreigners from 2018. With regard to unlawful residence, the return decision ${ }^{74}$ is issued as well as the decision about placement in the RC..$^{75}$ The restriction of the freedom of movement ${ }^{76}$ by placing a foreigner in a $\mathrm{RC}$ (optional only for the shortest period of time necessary for forceful departure) is needed for ensuring forceful departure and return of the Citizens of the Third Countries (hereinafter: CTC) which could not have been ensured by applying less severe $^{77}$ measures. Crucial in determining of the mentioned situation is the individual assessment in accordance with the proportionality principle. ${ }^{78}$ It is also to be pointed out that in the decision-making process in this special administrative

69 See also Art. 33 of the Constitution of the Republic of Croatia, OG, No. 56/90, 135/97, 08/98, $113 / 00,124 / 00,28 / 01,41 / 01,55 / 01,76 / 10,85 / 10,05 / 14$ (hereinafter: Constitution of the RC)

70 About principle of proportionality see also Art. 16 (1) of the Constitution of the RC

71 Reception Centre for Foreigners Ježevo, Transit Reception Centre for Foreigners Trilj and Transit Reception Centre for Foreigners Tovarnik. Art. 1 (2) of the Ordinance on stay in the Reception Centre for Foreigners, OG, No. 101/18. See Art. 91 (5.4.5) Code on Inner Organisation of the Ministry of the Interior, OG, No. 70/12, 140/13, 50/14, 32/15, 11/17, 129/17, 5/18, 109/18, 24/19 (hereinafter: Code)

72 See Art. 76 (5.4.) (Border administration) and 84 (5.4.3.) (Services for unlawful migrations) of the Code

73 Police Department or Police station

74 Art. 109 and 112 of the FA

75 Art. 135 of the FA

76 Art. 130 of the FA

77 Art. 132 of the FA. On applying less severe measures the MI reaches a decision through competent $\mathrm{PD} / \mathrm{PS}$. (for a period of time until forceful departure depending on which of the (4) are appropriate for the circumstances of the given case)

78 See Art. 6 of the GAPA 
area specific circumstances must be taken into consideration along with the procedural standards. In addition, special emphasis is to be put on rightfully applying the principle of efficiency and proportionality, along with right to legal remedy. ${ }^{79}$ The placement decision (or prolongation of the placement for a maximum of 12 months ${ }^{80}$ in $\mathrm{RC}$ is reached by the MI through competent PD/PS. It is not allowed to place an appeal against the reached decision, but it is, however, possible to start an administrative dispute. Upon the reaching of the decisions, the case file is delivered to the $\mathrm{AC}$ (by mail or fax), that is then obligated to reach a decision in the period of five days by which the placement decision is dismissed or confirmed.$^{81} \mathrm{CTC}$ is notified about all the actions taken during the decision-making process. There has to be an explanation of the circumstances in each individual case, which indicate the justification of placement in the centre (up to 6 months) due to the presence of risk of avoiding the obligation of leaving EEA or RC. When compared to starting and managing administrative disputes, the presence of certain exceptions and specificities is noticeable. The administrative dispute is, therefore, not started by filing a law suit in a period of 30 days, ${ }^{82} \mathrm{PD} / \mathrm{PS}$ delivers the case file to the AC, there is a proscribed deadline by which the AC needs to make a decision about dismissing or confirming the decision reached by the MI, the oral hearing is organised exceptionally (for minors). The case described is thus a quasi-administrative dispute, ${ }^{83}$ in which the $\mathrm{AC}$ decides about other legally proscribed cases. ${ }^{84}$

Special emphasis is put on the specificity of the administrative disputes in which under aged children of foreigners are involved. In accordance with the 2018 FA amendments, it is proscribed that the court needs to organise an oral hearing if the CTC is a minor. ${ }^{85}$ The provisions regarding the obligatory oral hearing ${ }^{86}$ in cases in which the $\mathrm{AC}$ enforces periodic control of the lawfulness of the decisions

\footnotetext{
79 See Art. 5-14 of the GAPA

80 Art. 134 and Art. $135(6,8)$ of the FA

81 See title 4 . of this paper

82 The deadlines for filing a lawsuit are set out in the Art. 24 of the ADA

83 See Decision of the U-III-1502/2007 from 9 July 2008 of the Constitutional Court of the Republic of Croatia

84 Art. 12 (2, p. 5) of the ADA

85 Art. 135 para 7 of the FA. See Decision of the Administrative Court in Osijek UsI-1331/18-5 from 24 October 2018, UsI-1390/18-4 from 16 November 2018, UsI-158/2019-4 from 4 February 2019

86 See Art. 7 of the ADA. The obligation of organising a public oral debate is one of the basic principles of the administrative dispute and it presented one of the key components in the judicial administration reform as well as in the process of forming new organisation of administrative judiciary in accordance with the administrative court's authorities regarding the decision-making processes. The exceptions to this rule are proscribed in Art. 36 of the ADA
} 
about the placement in the $\mathrm{RC}$ for foreigners ${ }^{87}$ have been erased. With respect to provisions of both, the principle of family unity, as well as the principle of efficiency, according to which the AC proceedings will be swift, without unnecessary delay and costs, the court has joined some cases for the purposes of conducting a unified procedure and reaching a common decision. ${ }^{88}$ The current legal regulation presents improvement, especially with regard to enforcing alternative measures for restricting the freedom of movement, proscribing the application of measures for ensuring the return and redefining the circumstances which may indicate the risk of avoiding the obligation of leaving EEA that is RC. Particular imperfections have been dealt with along with the process of harmonisation with the EU Directive from 2016, ${ }^{89}$ terminological harmonisation was necessary due to certain legislative definitions, whereas nomotechnical improvements were made with the aim of allowing undoubtful enforcement of the FA.

\section{ANALYSES OF THE ADMINISTRATIVE-COURTS CASE LAW}

Emphasis is put on the analyses of the judicial practice of the Administrative Courts in Zagreb and Osijek in administrative matters regarding restrictions on freedom of movement, and detention in reception centres-Reception Centre for Foreigners in Ježevo (hereinafter: RCJ) (Zagrebačka County) and Transit Reception Centre for Foreigners in Tovarnik (hereinafter: TRCT) (Vukovarsko-srijemska County). ${ }^{90}$ From available statistical data of judicial practice of the Administrative Court in Osijek (hereinafter: AC OS) and in relation to court cases in which administrative disputes regarding restrictions on freedom of movement were imposed, a total of 128 court cases were received. In 10 cases from 2018 the plaintiffs filed a lawsuit for assessment of the lawfulness of a decision of the MI in which restrictions on freedom of movement were imposed by detention in RC. In these disputes, 9 cases ended in a way that the law suit was dismissed, ${ }^{91}$ while 1 case ended by reaching

$87 \ldots$ „...in 2017 the EU Commission reached a revised Return Directive which proscribes the manner in which periodic control is conducted, which, therefore, needed adjusting with the FA provisions..." See Final Proposal of the Foreigners Act, Klasa: 022-03/18-01/53, Ur. broj: 65-18-02, P.Z.E. No. 328, Zagreb, 5 April 2018, pp. 25

88 See Decision of the Administrative Court in Osijek, UsI-158/19-4 from 4 February 2019

89 Directive (EU) 2016/801 of the European Parliament and of the Council of 11 May 2016 on the conditions of entry and residence of third-country nationals for the purposes of research, studies, training, voluntary service, pupil exchange schemes or educational projects and au pairing, [https://eur-lex. europa.eu/legal-content/en/ALL/?uri=CELEX\%3A32016L0801] Accessed 23.03.2019

90 About seats and area of competence of the Administrative Court in Osijek (hereinafter: AC OS) and Administrative Court in Zagreb see Art. 8 para 1 and para 4 Law on Areas and Seats of Courts, OG, No. 67/18. See Art. 135 (9) of the FA

91 Art. 57 para 1 of the ADA. See also Judgment of the Administrative Court in Osijek, UsI-626/1825 from 25 May 2018, UsI-623/18-16 from 25 May 2018 in which the court has dismissed the law 
a judgment in which the law suit was accepted. Appeals were made against the decisions reached by the AC OS (in all 10 cases). All the appeals were dismissed by the High Administrative Court in Zagreb. ${ }^{92}$ Furthermore, in cases in which the $\mathrm{AC}$ OS was the body determining the law suits regarding the legitimacy of the decision reached by the MI about the placements, there were totally 10 cases in 2017, 59 cases in 2018 and 49 cases in 2019. 6 cases ended with the suspension of the reached decision, 9 cases were resolved by dismissing the decision reached by the MI and in 103 cases the decisions were declared lawful. It was not allowed to place an appeal against the reached decisions. Another point to emphasize, are the cases in which minors were involved.${ }^{93}$ In all such cases AC OS has reached the decision $s^{94}$ which were in accordance with the decision reached by the MI regarding the placement of foreigners in the centre for the purposes of ensuring forceful departure and return based on Art. 135 (4) FA. When analysing the accessible data due to judicial control of lawfulness of movement restrictions by placement in $\mathrm{RC}$, it is to be concluded that $\mathrm{AC}$ have mostly confirmed the decision of the

suit for nullification of the decision reached by the MI regarding the placement in TRCT. The case included a number of minors for whom there existed justified reasons for restricting the freedom of movement due to establishing and checking the identity and citizenship. The specificity of these cases is also visible in difficulty to find the interpreter for Parsi or Pashto (the languages they understood)

92 See some of them Judgment of the High Administrative Court of the Republic of Croatia Usž-3203/183 from 21 August 2018, Usž-3452/18-2 from 30 August 2018, Usž-3547/18-2 from 28 November 2018, Usž-3700/18-2 from 28 November 2018. In judgement Usž-3203/18-3 from 21 August 2018 dismissed the law suit as unfounded and confirmed the decision reached by the AC OS, since it established the presence of justified reasons for restricting the freedom of movement and placement in the centre due to the lack of the plaintiff's identity. The necessity for establishing one's identity is a special reason for which it is allowed to restrict someone's freedom (none of the 12 persons found together in a group was in possession of any type of evidence regarding the identity or kinship, they claimed to be the members of the same family, but have presented different last names, there has been a large number of minors). Moreover, in judgement Usž-3452/18-2 from 30 August 2018 points out that the plaintiff along with the group of people unlawfully entered the RC territory from the Republic of Serbia (hereinafter: Rs) and was therefore reasonably founded that he sought international protection in RS or other EU member country, which presents the reason for restriction of freedom of movement (unknown identity). The HAC, moreover, states that the plaintiff wrongfully claims he was unable to declare himself/herself in the administrative procedure due to the fact there was no interpreter for Parsi thereby questioning the honouring of the basic human rights guaranteed by the Constitution of the RH (unequal position). In the analysed cases plaintiffs argue that it was not possible to determine the basis of individual assessment for not applying less severe measures in order to impose movement restrictions

93 Decision of the Administrative Court in Osijek, UsI-25/18-4 from 12 January 2018, UsI-123/18-4 from 19 February 2018, UsI-168/18-4 from 27 February 2018, UsI-1266/18-2 from 4 October 2018, UsI-1427/18-2 from 26 November 2018, UsI-174/2019-3 from 8 February 2019

94 According to Art. 135 para 4 of the FA, it is proscribed that AC reaches the decision upon which the prior reached decision is either dismissed or confirmed. The judicial practice of the AC OS shows that the judgements were made in form of decisions 
MI. This is so due to the fact that in individual decisions, circumstances ${ }^{95}$ were justifiably determined, which indicated the presence of risk of avoiding the departure of EEA or RC in accordance with Art. 133 (2) of the FA. ${ }^{96}$ Moreover, these were unlawful entries and stays of foreigners within the territory of the RC, which AC made undoubtedly clear by insight in records about taking depositions from foreigners which were enclosed in the case file. Additionally, they explain that the forceful departure of foreigners could not have been ensured by applying less strict measures (Art. 131 (1) and 132 (1) of the FA). ${ }^{97}$ Having considered the fact that the foreigner's freedom of movement, which is one of the basic human rights, is hereby restricted by placement in RC, ACs have declared this not being opposed to achieving its lawfully proscribed purpose and is in proportion with the necessity for movement restriction. There have been, however, some cases in which the decisions of MI have been dismissed. ${ }^{98}$ Some of the reasons for reaching those decisions are that it is not enough for a foreigner not to have an identification document or it is not clear whether the individual assessment has been performed since no reasons for the maximum length of the forceful placement period have been provided or the case file has not been delivered. Another possibility is that the decision does not explain how the conclusive fact (unclear exact identity of a foreigner) has been determined or there might even be a contradiction between the decision and its clarification etc. This is all indicative of the seriousness of the responsibility assigned to the competent administrative and judicial authorities. The fact is more than obvious when comparing the necessity for ensuring minimal legislative guarantees when reaching decisions by conducting lawful and transparent procedures to ensure effective legal protection of individuals' rights and interests. These are both extremely complicated legal and highly sensitive life situations in which under aged children ${ }^{99}$ are often involved as well, which makes the AC role in these cases even more important and demanding.

\section{CONCLUSION}

Human rights and freedoms are subject of numerous documents at European level. Basic framework on irregular migration is set in ECHR in Article 5 which

\footnotetext{
95 The most frequent reasons are (considering the unlawful residence) the lack of travel documents or identification, residence address or financial means

96 Decision of the Administrative Court in Zagreb, UsI-3702/18-2 from 18 October 2018

${ }_{97}$ See Decision of the Administrative Court in Osijek, UsI-168/18-4 from 27 February 2018

98 Decision of the Administrative Court in Zagreb, UsI-3797/18-2 from 30 October 2018, Decision of the Administrative Court in Osijek, UsI-169/18-4 from 27 February 2018, Decision of the Administrative Court in Osijek, UsI-30/19-2 from 11 January 2019, Decision of the Administrative Court in Osijek, UsI-185/19-2 from 12 February 2019

$99 \quad$ See Ar. 5 (a) of the Return Directive
} 
guarantees right to liberty and security regardless of status, nationality or citizenship. ECtHR case law sets clear standards on the restriction of the mentioned right for national administrative bodies and courts on national level, such as guidelines on lawful detention of migrants. Review procedures before national courts should be speedy and effective when deciding on lawfulness of the decision on detention and on the decision for prolongation of the detention. Nonetheless, wide discretion is left for High Contracting Parties in the aspect of the protection of the national security.

The Charter on Fundamental Freedoms of the EU in Article 45 (2) provides basic framework for the residence of the third-country nationals in the EU. Returns Directive sets rules on the detention and on the procedures regarding returning irregular migrants. Immigrants should be treated with dignity and respect. CJEU has very important role in the achievement of mentioned standards through its rulings in cases of illegal migration, especially in preliminary procedures where national courts refers questions to CJEU on the interpretation of the EU law. European countries should respect Council of Europe and EU standards in order to avoid or at least minimize the violation of rights of vulnerable groups in the migration process.

The current legal regulation (FA) presents improvement, especially with regard to enforcing alternative measures for restricting the freedom of movement, proscribing the application of measures for ensuring the return and redefining the circumstances which may indicate the risk of avoiding the obligation of leaving EEA that is RC. When analysing the accessible data due to judicial control of lawfulness of movement restrictions by placement in $\mathrm{RC}$, it is to be concluded that $\mathrm{AC}$ have mostly confirmed the decision of the MI.

Our opinion is that the standards of urgency of proceedings and decision making (speedy judicial review) by administrative (MI) and judicial (AC) authorities are being obeyed. Moreover, the procedural safeguards in the cases regarding the decision making about unlawful stay are being fulfilled since the foreigners have the right to effective remedy, necessary linguistic assistance (an interpreter), giving statements, receiving representation, (free) legal aid. Conclusively, we emphasize that based on the review of the administrative-judicial decision it is to be concluded that the standards guaranteed by Art. 15-18 of the Return Directive (Detention for the Purpose of Removal) are being ensured. 


\section{REFERENCES}

\section{BOOKS AND ARTICLES}

1. Amnesty International, Punishement without a crime-Detention of Migrants and Asylium Seekers in Cyprus, 2012

2. Baldaccini, A., The Return and Removal of Irregular Migrants under EU Law: An Analysis of the Returns Directive, European Journal for Migration and Law, vol. 11, 2009, pp. 1-17

3. Baldaccini, A. The Eu Directive on Return: Principles And Protests, Refugee Survey Quarterly, Vol. 28, No. 4 UNHCR [2010], p. 126., pp. $114-138$

4. Basilien-Gainche, M-L., Immigration Detention under the Return Directive: The CJEU Shadowed Lights, European Journal of Migration and Law, vol. 17, 2015, pp. 104-126

5. Bulli, G., Soare, S. C. Immigration and the Refugee Crisis in a New Immigration Country: The Case of Italy, Croatian and Comparative Public Administration, Vol. 18, No. 1, 2018, pp. 127-156

6. Costello, C., Human Rights of Migrants and Refugees in European Law, Oxford University Press, 2016

7. Doncea, A., Illegal migration - a current European issue, European Journal of Public Order and National Security, Vol. 2, No. 4, 2015, pp. $21-26$

8. Đerđa, D.; Šikić, M., Komentar Zakona o upravnim sporovima, Novi Informator, Zagreb, 2012

9. Gregurović, S.; Mlinarić, D., The Challenges of Migration Policies in Croatia: Migration History, Trends and Prospects, AEMI Journal, Vol. 10, special issue on Migration History Matters 2012, pp. 99-113

10. Hellenthal, M., Granične kontrole kao dio nacionalnog i europskog sustava za kontrolu kriminala $i$ migracije $=$ GrenzkontrollenalsTeilnationalen und europaeischen Systems zurKriminalitaets-und Wanderugkontrolle, translation from German: Dragica Dragičević, Izbor članaka iz stranih časopisa, vol. 35, No. 1, 1995, pp. 20-34

11. IOM Submission to the Working Group on Arbitrary Detention, International Standards on Immigration Detention and non-custodial measures, 2011, pp. 1-15

12. Ivanda, S., Suvremene ilegalne migracije u Republici Hrvatskoj, Policija i sigurnost, vol. 11, No. 1-3, 2002, pp. 82-92

13. Ivanda, S., Šuperina, M., Migracije, granična policija, legalni prelasci i krijumičarenje ljudi preko državne granice, Pravni vjesnik, Vol. 16, No. 3-4, 2000, pp. 277-291

14. Kitsakis, Y., Protecting Migrants under the European Convention on Human Rights and the European Social Charter, Council of Europe, 2013

15. Lalić Novak, G., The Principle of Non-Refoulementand Access to Asylum System: Two Sides of the Same Coin, Migracijske i etničke teme, vol. 31, No. 3, 2015, pp. 365-385

16. Lambert, H., The position of aliens in relation to the European Convention on Human Rights, Council of Europe Publishing, Strasbourg, 2007

17. Medvedović, D., Novi sustav upravnog sudovanja, in: Đerđa, D., Šikić, M., Komentar Zakona o upravnim sporovima, Novi informator, Zagreb, 2012., pp. 17-75 
18. Morehouse, C., Blomfiled, M., Irregular Migration in Europe, migration Policy Institute, 2011

19. Practical Guide on Admissibility Criteria, Council of Europe, last updated 31 December 2018. Accessed 19 February 2019.

20. Rajko, Alen, Novi Zakon o upravnim sporovima: odluke Upravnog suda RH u prvostupanjskome upravnom sporu, Hrvatska pravna revija, vol. 10, No. 10, 2010, pp. 84-91

21. Rodin, S., Načelo non-refoulement u hrvatskom pravu. Informator : instruktivno-informativni list za ekonomska i pravna pitanja, vol. no. 6048, 2012, pp. 1-3

22. Speer, B., External and Internal Effects of How Austria Has Handled the Refugee Crisis, Croatian and Comparative Public Administration, Vol. 18, No. 2, 2018, pp.247-268

23. Šikić, M., Pravo na suđenje u razumnom roku u upravnosudskim postupcima - novi problemi i izazovi, IN: Uzelac, A.; Garašić, J.; Maganić, A. (eds.)Zbornik radova u čast 70. rođendana prof. dr. sc. Mihajla Dike-Djelotvorna pravna zaštita u pravičnom postupku, Izazovi pravosudnih transformacija na jugu Europe-Liberamicorum Mihajlo Dika., Sveučilište u Zagrebu, Pravni fakultet, 2013, pp 977-992

24. Thielemann, E-R., How Effective are National and Eu Policies in the Area of Forced Migration?, Refugee Survey Quarterly, vol. 31, No. 4, 2012, pp. 21-37

\section{COURT OF JUSTICE OF THE EUROPEAN UNION}

1. Consolidated versions of the Treaty on European Union and the Treaty on the Functioning of the European Union, OJ C 202

2. The Charter of Fundamental Rights of the European Union (2016/C 202/02)

3. European Parliament and Council Directive 2008/115/EC on common standards and procedures in Member States for returning illegally staying third-country nationals [2008] OJ L $348 / 98$

4. Case C-646/16 - Jafari - Judgmentofthe Court (Grand Chamber) of 26 July 2017

5. Case C-240/17 - E - Judgmentofthe Court (Fifth Chamber) of 16 January 2018

6. Case C-225/16 - Ouhrami - Judgmentofthe Court (SecondChamber) of 26 July 2017

7. Case C-181/16 - Gnandi - Judgmentofthe Court (Grand Chamber) of 19 June 2018

8. Case C-82/16 - K.A. and Others- Judgmentofthe Court (Grand Chamber) of 8 May 2018

9. Case C-18/16 - K. - Judgmentofthe Court (FourthChamber) of 14 September 2017

10. Case C-601/15 - PPU - N. - Judgmentofthe Court (Grand Chamber) of 15 February 2016

11. Case C-218/15 - Paoletti and Others - Judgmentofthe Court (Fifth Chamber) of 6 October 2016

12. Case C-133/15 - Chavez-Vilchezand Others- Judgmentofthe Court (Grand Chamber) of 10 May 2017

13. Case C-47/15 - Affum - Judgmentofthe Court (Grand Chamber) of 7 June 2016

14. Case C-544/13 - Abcur - Judgmentofthe Court (Third Chamber) of 16 July 2015

15. Case C-249/13 - Boudjlida - Judgmentofthe Court (Fifth Chamber), 11 December 2014

16. Case C-166/13 - Mukarubega - Judgmentofthe Court (Fifth Chamber), 5 November 2014 
17. Case C-225/12 - Demir - Judgmentofthe Court (SecondChamber), 7 November 2013

18. Case C-383/13 PPU $G$ and $R v$ Staatssecretaris van VeiligheidenJustitie, PRESS RELEASE No $100 / 13$

19. Case C-146/14 PPU Bashir Mohamed Ali Mahdi, PRESS RELEASE No 80/14

\section{ECHR (ECtHR case law)}

1. Judgement Abdolkhan and Karimnia v. Turkey (2009), application no. 30471/08

2. Judgement Alimov v. Turkey (2016), application no. 14344/13

3. Judgement Amerkhanov v. Turkey (2018), application no. 16026/12

4. Judgement Batyrkhairov v. Turkey (2018), application no.69929/12

5. Judgement Berdzenshvili and Others v. Russia (2017), application nos. 14594/07, 14597/07, $14976 / 07,14978 / 07,15221 / 07,16369 / 07$ and 16706/07

6. Judgement Chahal v. UK (1996), application no. 22414/93

7. Judgement Čonka v. Belgium (2002), application no. 51564/99

8. Judgement Djalti v. Bulgaria (2013), application no. 31206/05

9. Judgement Georgia v. Russia (I) (2014), application no. 13255/07

10. Judgement Hirsi Jamaa and Others v. Italy (2012), application no. 27765/09

11. Judgement Kadem v. Malta (2003), application no. 55263/00

12. Judgement Khlaifia and Others v. Italy (2016), application no. 16483/12

13. Judgement M. A. v. Cyprus (2013) application no. 41872/10

14. Judgement $M$. and Others $v$. Bulgaria (2011), application no.41416/08

15. Judgement Rehbock v. Slovenia (2000), application no. 29462/95

16. Judgement Saadi v. UK(2008), application no. 13229/03

17. Judgement Sarban v. Moldova (2006), application no. 3456/05

18. Judgement Sharifi and Others v. Italy and Greece (2015), application no.16643/09

19. Judgement Shioshvili and Others v. Russia (2017), application no.19356/07

20. Judgement Suso Musa v. Malta (2013), application no. $\underline{42337 / 12}$

21. Judgement Tehrani and Others v. Turkey (2010), application nos. 32940/08, 41626/08, $43616 / 08$

22. Judgement Z. N. S. v. Turkey (2010), application no. $21896 / 08$

\section{LIST OF NATIONAL REGULATIONS, ACTS AND COURT DECISIONS}

1. Act on International and Temporary Protection, OG, No. 70/15, 127/17

2. Administrative Disputes Act, OG, No. 20/10, 143/12, 152/14, 94/16, 29/17

3. Code on Inner Organisation of the Ministry of the Interior, OG, No. 70/12, 140/13, 50/14, $32 / 15,11 / 17,129 / 17,5 / 18,109 / 18,24 / 19$

4. Constitution of the Republic of Croatia, OG, No. 56/90, 135/97, 08/98, 113/00, 124/00, 28/01, 41/01, 55/01, 76/10, 85/10,05/14 
5. Courts Act, OG, No. 28/13, 33/15, 82/15, 82/16, 67/18

6. Foreigners Act, OG, No. 130/11, 74/13, 69/17, 46/18

7. General Administrative Procedure Act, OG, No. 47/09

8. Law on Areas and Seats of Courts, OG, No. 67/18

9. Ordinance on Stay in the Reception Centre for Foreigners, OG, No. 101/18

10. Ordinance on Treatment of Citizens of the Third Countries, OG, No. 68/2018

11. Final Proposal of the Foreigners Act, Klasa: 022-03/18-01/53, Ur. broj: 65-18-02, P.Z.E. No. 328, Zagreb, 5 April 2018, pp. 1-203

12. Decision of the U-III-1502/2007 from 9 July 2008 of the Constitutional Court of the Republic of Croatia

13. Decision U-III-3124/2018 from 17 October 2018 of the Constitutional Court of the Republic of Croatia

14. Decision U-IIIBi/1385/2018 from 18 December 2018 of the Constitutional Court of the Republic of Croatia

15. Decisions of the Administrative Court in Osijek, UsI-1331/18-5 from 24 October 2018, UsI-1390/18-4 from 16 November 2018, UsI-158/2019-4 from 4 February 2019

16. Decisions of the Administrative Court in Osijek, UsI-25/18-4 from 12 January 2018, UsI123/18-4 from 19 February 2018, UsI-168/18-4 from 27 February 2018, UsI-1266/18-2 from 4 October 2018, UsI-1427/18-2 from 26 November 2018, UsI-174/2019-3 from 8 February 2019

17. Decisions of the Administrative Court in Osijek, UsI-169/18-4 from 27 February 2018, UsI-30/19-2 from 11 January 2019, UsI-185/19-2 from 12 February 2019

18. Decisions of the Administrative Court in Zagreb, UsI-3702/18-2 from 18 October 2018, UsI-3797/18-2 from 30 October 2018

19. Judgment of the Administrative Court in Osijek, UsI-626/18-25 from 25 May 2018, UsI623/18-16 from 25 May 2018

20. Judgments of the High Administrative Court of the Republic of Croatia Usž-3203/18-3 from 21 August 2018, Usž-3452/18-2 from 30 August 2018, Usž-3547/18-2 from 28 November 2018, Usž-3700/18-2 from 28 November 2018

21. Universal Declaration on Human Rights, General Assembly Resolution 217 A

22. European Convention on Human Rights, OG-International Agreements No. 18/97, 6/9, 8/99, 14/02)-amended by Protocol No. 14, ECHR (OG- International Agreements No. 1/06)

\section{WEBSITE REFERENCES}

1. [www.nn.hr] Accessed 20.02.2019

2. [www.curia.eu] Accessed 20.02.2019

3. [https:/www.coe.int/en/web/european-commission-against-racism-and-intolerance/croatia] Accessed 20.02.2019 
4. [https://www.ohchr.org/en/Issues/Migration/Pages/MigrantsinLargeMovements.aspx] Accessed 07.03.2019

5. [https://ec.europa.eu/knowledge4policy/dataset/ds00039_en] Accessed 07.03.2019

6. Crepéau, F., Statement by the UN Special Rapporteur on the Human Rights of migrants, PGA Plenary Session-Criminalization of Migrants, New York, 2013, p. 1, [https://www.ohchr. org/_layouts/15/WopiFrame.aspx?sourcedoc=/Documents/Issues/SRMigrants/Speech/ StatementPGAPlenaryCriminalization.doc\&action $=$ default $\&$ DefaultItemOpen $=1] \quad$ Accessed 08.02.2019

7. European Committee for the Prevention of Torture and Inhuman or Degrading Treatment or Punishment (CPT) factsheet form March 2017, CPT/Inf (2017)3, p. 1, [https://rm.coe. int/16806fbf12] Accessed 01.03.2019

8. European Commission, Progress Report on the Implementation of the European Agenda on Migration, COM (2018) 301 final, 18 May 2018, p. 5, [https://ec.europa.eu/home-affairs/ sites/homeaffairs/files/what-we-do/policies/european-agenda-migration/20180516_progress-report-european-agenda-migration_en.pdf] Accessed 04.03.2019

9. Frantziou, E.; Staiger, U.; Chaytor, S., Refugee Protection, Migration and Human Rights in Europe, UCL policy briefing-May 2014, p. 2, [https:/www.ucl.ac.uk/public-policy/sites/ public-policy/files/migrated-files/Refugee_protection_FINAL.pdf] Accessed 07.03.2019

10. Geddes A.; Achtnich M., Research-Policy Dialogues in the European Union. in: Scholten P.; Entzinger H.; Penninx R.; Verbeek S. (eds) Integrating Immigrants in Europe. IMISCOE Research Series. Springer, Cham, 2015, [https://link.springer.com/chapter/10.1007/978-3-319-16256-0_16] Accessed 07.03.2019

11. Guide on Article 5 of the European Convention on Human Rights, p. 26, last updated 31. 12. 2018, [https://www.echr.coe.int/Documents/Guide_Art_5_ENG.pdf] Accessed 19.02.2019

12. Guide on Article 4 of Protocol No. 4 to the European Convention on Human Rights, Council of Europe, p. 6, last updated 31 December 2018., [https://www.echr.coe.int/Documents/ Guide_Art_4_Protocol_4_ENG.pdf] Accessed 20.02.2019

13. Joint Statement of heads of police Services, [https://www.mup.hr/UserDocsImages/topvijesti/2016/veljaca/migranti_sastanak/joint_statement.pdf]. Accessed 04.03.2019

14. The Pilot-Judgment Procedure Information Note issued by the Registrar, [https://www.echr. coe.int/Documents/Pilot_judgment_procedure_ENG.pdf] Accessed 08.02.2019

15. Report of the Special Rapporteur on the human rights of migrants, A/HRC/38/41, 4 May 2018, [https://reliefweb.int/sites/reliefweb.int/files/resources/G1812517.pdf] Accessed 08.02.2019

16. Sitaropoulos, N., Judicial Review of Migrant Detention in Europe - In Search of Effectiveness and Speedines, (OxHRH Blog, 27 January 2014) [http://humanrights.dev3.oneltd. $\mathrm{eu} /$ ?p=4126], [http://ohrh.law.ox.ac.uk/judicial-review-of-migrant-detention-in-europe-insearch-of-effectiveness-and-speediness] Accessed 08.02.2019 